\title{
Effect of Pre-Soaking of Corms in to Plant Growth Regulators on Growth and Flowering of Gladiolus (Gladiolus grandiflorus L.) cv. American Beauty
}

\author{
Rashmi* and Bhagwan Deen \\ Department of Horticulture, N.D. University of Agriculture and Technology, \\ Kumarganj, Faizabad-224 229, U.P., India \\ *Corresponding author
}

Keywords

Pre-soaking, Plant growth, Flowering.

Article Info

Accepted:

07 October 2017

Available Online:

10 December 2017

\section{A B S T R A C T}

The research work entitled "Effect of pre-soaking of corms into plant growth regulators on growth and flowering of Gladiolus (Gladiolus grandiflorus L.) cv. American Beauty" was conducted at the Main Experiment Station, Horticulture, N.D. University of Agriculture and Technology, Kumarganj, Faizabad (U.P.) during the years 2013-14 and 2014-15. The corms were pre-soaked in different plant growth regulators as IAA $(100,200 \mathrm{ppm}), \mathrm{GA}_{3}$ (100, 200 ppm), NAA (100, 200 ppm), BA (100, 200 ppm), Ethrel (100, 200 ppm), ALAR $(100,200 \mathrm{ppm})$ and Maleic hydrazide $(100,200 \mathrm{ppm})$ for $12 \mathrm{hrs}$ as fifteen treatments which were replicated three times by Randomized Block Design (RBD). The observations were recorded at regular intervals for growth and flowering characters of gladiolus. The different characters like days taken in germination, plant height, number of leaves, leaf width, diameter of corms, number of florets/spike, spike length, spike weight, days taken for spike initiation and days taken for first floret to open were significantly improved by the use of $\mathrm{GA}_{3} @ 200 \mathrm{ppm}$ over all other treatments while the treatment comprised $\mathrm{MH}$ 200 ppm was showed lowest result for all chracters during both (2013-14 and 2014-15) the years of experimentation.

\section{Introduction}

Gladiolus (Gladiolus grandiflorus L.) is also known as the Queen of Bulbous Flowers owing to its brilliant colors, varying size, massive form, attractive shapes and excellent shelf life of flower spike and florets. It is grown for its attractive spike as cut flower and also in flower beds in gardens during winter. The conventional production system of gladiolus allows to get usually one sprout and one daughter corm from a mother corm but sprouting of more buds from a single corm favors to increase in production of corms. The minimum control over vegetative and floral traits is another drawback of conventional system, which is not in favor of meeting the market demands. The control over flowering time and floral characteristics according to the demand of market has been achieved in many cut flowers by adopting modern production techniques including the use of plant growth regulators (PGRs). The application of PGRs has become the part of their cultural practices in many ornamental plants to modify their vegetative and floral traits. Plant growth regulators are the organic chemical compounds which modify or regulate physiological processes in plants when used in small concentrations. The application of PGRs is modern techniques which have become the part of their cultural 
practices in many ornamental plants to modify their vegetative and floral traits. There are different application methods of PGRs including foliar application, pre-plant soaking and drenching but foliar application is the most common method being practiced in ornamental plants. The application of growth regulators such $\mathrm{GA}_{3}$ have been earlier reported to enhance the growth and yield of gladiolus (Umrao et al., 2005). Effect of plant growth regulators on growth and flowering of gladiolus (Baskaran and Misra, 2007) Preplant dipping of planting material in a chemical solution is now becoming a popular method among commercial growers (Schnelle et al., 2005). Hence the present study was conducted to find the effect of pre-soaking of corms into plant growth regulators on vegetative and floral production of gladiolus.

\section{Materials and Methods}

This experiment conducted was carried out at the Main Experiment Station, Department of Horticulture, Narendra Deva University of Agriculture and Technology, Kumarganj, Faizabad (U.P.) during 2013-14 and 2014-15. Soil of the experimental plot was sandy loam, uniform in texture and well drained. Well decomposed FYM @ 10 kg per sq. m was applied at the time of land preparation to all treatments. Recommended dose of NPK (300:200:200 kg/ha) was also applied. The corms were pre- soaked in solution of plant growth regulators for $12 \mathrm{hrs}$. The experiment was conducted in Randomized Block Design (RBD) with fifteen treatments as $\mathrm{T}_{1}$ :Control (Water spray), $\mathrm{T}_{2}$ :IAA- $100 \mathrm{ppm}, \mathrm{T}_{3}$ :IAA$200 \mathrm{ppm}, \mathrm{T}_{4}: \mathrm{GA}_{3}-100 \mathrm{ppm}, \mathrm{T}_{5}: \mathrm{GA}_{3}-200 \mathrm{ppm}$, $\mathrm{T}_{6}: \mathrm{NAA}-100 \mathrm{ppm}, \mathrm{T}_{7}: \mathrm{NAA}-200 \mathrm{ppm}, \mathrm{T}_{8}: \mathrm{BA}-$ 100ppm, $\quad \mathrm{T}_{9}: \mathrm{BA}-\quad 200 \mathrm{ppm}, \quad \mathrm{T}_{10}$ :Ethrel100ppm, $\mathrm{T}_{11}$ :Ethrel- 200ppm, $\mathrm{T}_{12}$ :ALAR100ppm, $\quad \mathrm{T}_{13}$ :ALAR-200ppm, $\quad \mathrm{T}_{14}: \mathrm{MH}-$ $100 \mathrm{ppm}$ and $\mathrm{T}_{15}: \mathrm{MH}-100 \mathrm{ppm}$ were replicated in three times. The observations were recorded as on days taken in germination, height of plant $(\mathrm{cm})$, number of leaves per plant, leaf width $(\mathrm{cm})$ and Diameter of corms $(\mathrm{cm})$. In floral characters were recorded as days of spike initiation, number of days taken for first floret to open, spike length $(\mathrm{cm})$, number of florets per spike and spike weight (g) were recorded at regular interval and critical differences were worked out at five per cent level to draw statistical conclusions during both the years of experimentations (2013-14 and 2014-15).

\section{Results and Discussion}

Result presented of two years data in table 1 and 2, reveal that the growth and flowering parameters of gladiolus plants were significantly altered due to the application of growth regulators. There were significant differences observed due to dipping of corms in different growth regulators. Dipping of corm into PGRs under the experiment significantly influence the days to complete germination of corm and minimum days were taken by $\mathrm{T}_{5} \quad\left(200 \mathrm{ppm} \quad \mathrm{GA}_{3}\right)$ showed significantly earlier germination over the untreated corm (control) during both the years of experimentation i.e. 2013-14 and 2014-15. The data in respect to days taken for complete germination of corms were significantly shortened (18.60 days) with treatment $\mathrm{T}_{5}$ (200ppm $\mathrm{GA}_{3}$ ) followed by $\mathrm{T}_{4}$ (18.51 days), $\mathrm{T}_{3}$ (19.80 days), $\mathrm{T}_{2}$ (19.00 days) and $\mathrm{T}_{6}(20.70$ days) as compared to control in 2013-14. In the year 2014-15, it was recorded 17.81 days with treatment $\mathrm{T}_{5}\left(200 \mathrm{ppm} \mathrm{GA}_{3}\right)$ followed by $\mathrm{T}_{4}$ (18.94 days), $\mathrm{T}_{3}$ (19.00 days), $\mathrm{T}_{2}$ (19.08 days) and $\mathrm{T}_{6}$ (19.17 days) as compared to control. However, no significant differences were noted in 2013-14 and 2014-15 among treatments except between $T_{9}$ and $T_{8}$ which were found to be significant in 2014-15.The maximum plant height was recorded with $\mathrm{T}_{5}$ (200ppm $\mathrm{GA}_{3}$ ) being $73.42 \mathrm{~cm}$ in 2013-14 and $82.22 \mathrm{~cm}$ in 2014-15 followed by $\mathrm{T}_{4}$ (71.46 and $80.51 \mathrm{~cm}), \mathrm{T}_{3}(70.72$ and $78.58 \mathrm{~cm})$ and $\mathrm{T}_{7}(69.25$ and $76.87 \mathrm{~cm})$ in $2013-14$ and 2014-15, respectively. 
Table.1 Effect of pre-soaking of corms into plant growth regulators on vegetative characters

\begin{tabular}{|c|c|c|c|c|c|c|c|c|c|c|c|}
\hline \multirow{2}{*}{\multicolumn{2}{|c|}{$\begin{array}{l}\text { Treatments } \\
\quad(\mathbf{p p m})\end{array}$}} & \multicolumn{2}{|c|}{ Plant Height (cm) } & \multicolumn{2}{|c|}{$\begin{array}{c}\text { No. of leaves } \\
\text { plant }^{-1}\end{array}$} & \multicolumn{2}{|c|}{ Leaf width $(\mathrm{cm})$} & \multicolumn{2}{|c|}{$\begin{array}{c}\text { Diameter of } \\
\operatorname{corm}(\mathbf{c m})\end{array}$} & \multicolumn{2}{|c|}{$\begin{array}{c}\text { Days taken in } \\
\text { germination }\end{array}$} \\
\hline & & 2013-14 & 2014-15 & 2013-14 & 2014-15 & 2013-14 & 2014-15 & 2013-14 & 2014-15 & 2013-14 & 2014-15 \\
\hline $\mathrm{T}_{1}$ & Control & 62.59 & 60.24 & 7.50 & 6.96 & 2.76 & 2.78 & 6.52 & 6.35 & 23.80 & 24.24 \\
\hline $\mathrm{T}_{2}$ & IAA 100 & 68.11 & 76.87 & 8.96 & 8.69 & 3.39 & 3.45 & 6.98 & 7.00 & 19.00 & 19.08 \\
\hline $\mathrm{T}_{3}$ & IAA 200 & 70.72 & 78.58 & 9.40 & 9.02 & 3.52 & 3.64 & 7.65 & 7.60 & 19.80 & 19.00 \\
\hline $\mathrm{T}_{4}$ & $\mathrm{GA}_{3} 100$ & 71.46 & 80.51 & 9.65 & 9.61 & 3.56 & 3.75 & 7.79 & 8.00 & 18.60 & 18.94 \\
\hline $\mathrm{T}_{5}$ & $\mathrm{GA}_{3} 200$ & 73.42 & 82.22 & 9.96 & 9.80 & 3.66 & 3.78 & 7.90 & 8.45 & 18.51 & 17.81 \\
\hline $\mathrm{T}_{6}$ & NAA 100 & 68.01 & 72.40 & 8.30 & 8.52 & 3.22 & 3.34 & 6.85 & 6.89 & 20.70 & 19.17 \\
\hline $\mathrm{T}_{7}$ & NAA 200 & 69.25 & 76.65 & 9.01 & 8.96 & 3.42 & 3.61 & 7.50 & 7.53 & 20.80 & 19.76 \\
\hline $\mathrm{T}_{8}$ & BA 100 & 67.90 & 69.44 & 8.28 & 8.04 & 3.14 & 3.33 & 6.76 & 6.76 & 22.86 & 22.34 \\
\hline $\mathrm{T}_{9}$ & BA 200 & 68.85 & 68.48 & 8.53 & 8.28 & 3.23 & 3.43 & 6.97 & 6.87 & 23.22 & 23.03 \\
\hline $\mathrm{T}_{10}$ & Ethrel 100 & 66.50 & 66.16 & 8.62 & 8.37 & 3.26 & 3.47 & 6.65 & 6.34 & 22.44 & 23.26 \\
\hline $\mathrm{T}_{11}$ & Ethrel 200 & 67.81 & 67.51 & 8.79 & 8.53 & 3.33 & 3.54 & 6.60 & 6.29 & 24.08 & 23.71 \\
\hline $\mathrm{T}_{12}$ & ALAR 100 & 59.98 & 57.22 & 7.01 & 6.58 & 2.64 & 2.86 & 6.39 & 6.30 & 24.24 & 24.78 \\
\hline $\mathrm{T}_{13}$ & ALAR 200 & 57.32 & 56.09 & 6.68 & 6.25 & 2.91 & 2.68 & 6.45 & 6.90 & 24.00 & 24.09 \\
\hline $\mathrm{T}_{14}$ & MH 100 & 58.42 & 57.63 & 6.57 & 6.40 & 2.29 & 2.55 & 6.16 & 6.14 & 25.70 & 26.20 \\
\hline $\mathrm{T}_{15}$ & MH 200 & 55.68 & 55.18 & 6.25 & 6.20 & 2.09 & 2.50 & 6.21 & 6.02 & 25.09 & 25.38 \\
\hline & SEm \pm & 2.62 & 2.74 & 0.33 & 0.32 & 0.12 & 0.12 & 0.27 & 0.27 & 0.87 & 0.87 \\
\hline & CD at $5 \%$ & 7.59 & 7.96 & 0.96 & 0.93 & 0.36 & 0.37 & 0.79 & 0.80 & 2.54 & 2.52 \\
\hline
\end{tabular}


Table.2 Effect of pre-soaking of corms into plant growth regulators on floral characters

\begin{tabular}{|c|c|c|c|c|c|c|c|c|c|c|c|}
\hline \multirow{2}{*}{\multicolumn{2}{|c|}{ Treatments }} & \multicolumn{2}{|c|}{$\begin{array}{l}\text { Days of spike } \\
\text { initiation }\end{array}$} & \multicolumn{2}{|c|}{$\begin{array}{l}\text { No. of days } \\
\text { taken for first } \\
\text { floret to open }\end{array}$} & \multicolumn{2}{|c|}{ Spike length(cm) } & \multicolumn{2}{|c|}{$\begin{array}{l}\text { No. of florets per } \\
\text { spike }\end{array}$} & \multicolumn{2}{|c|}{ Spike weight(g) } \\
\hline & & 2013-14 & 2014-15 & 2013-14 & 2014-15 & 2013-14 & 2014-15 & 2013-14 & 2014-15 & 2013-14 & 2014-15 \\
\hline $\mathrm{T}_{1}$ & Control & 105.00 & 106.63 & 118.55 & 120.19 & 70.36 & 73.40 & 11.66 & 10.79 & 32.80 & 37.78 \\
\hline $\mathrm{T}_{2}$ & IAA 100 & 96.70 & 96.15 & 111.05 & 113.14 & 87.95 & 95.90 & 13.30 & 12.89 & 37.16 & 46.22 \\
\hline $\mathrm{T}_{3}$ & IAA 200 & 94.06 & 95.08 & 109.39 & 112.92 & 89.12 & 96.84 & 13.45 & 13.87 & 38.60 & 47.16 \\
\hline $\mathrm{T}_{4}$ & $\mathrm{GA}_{3} 100$ & 91.63 & 90.82 & 106.22 & 103.87 & 90.78 & 98.26 & 13.56 & 13.81 & 39.80 & 49.39 \\
\hline $\mathrm{T}_{5}$ & $\mathrm{GA}_{3} 200$ & 88.35 & 83.26 & 103.36 & 96.23 & 91.11 & 99.00 & 13.93 & 14.11 & 40.68 & 50.82 \\
\hline $\mathrm{T}_{6}$ & NAA 100 & 99.03 & 98.77 & 114.74 & 116.43 & 87.12 & 95.00 & 12.95 & 12.77 & 36.60 & 46.00 \\
\hline $\mathrm{T}_{7}$ & NAA 200 & 97.28 & 97.76 & 113.75 & 115.10 & 88.50 & 95.81 & 13.32 & 13.00 & 37.88 & 46.97 \\
\hline $\mathrm{T}_{8}$ & BA 100 & 99.01 & 106.39 & 114.17 & 120.00 & 81.62 & 91.70 & 12.08 & 12.11 & 35.28 & 45.27 \\
\hline $\mathrm{T}_{9}$ & BA 200 & 100.14 & 103.56 & 115.76 & 117.10 & 80.99 & 89.99 & 12.45 & 12.44 & 36.36 & 46.29 \\
\hline $\mathrm{T}_{10}$ & Ethrel 100 & 103.34 & 107.61 & 119.71 & 121.65 & 80.78 & 87.52 & 12.58 & 11.33 & 36.72 & 44.24 \\
\hline $\mathrm{T}_{11}$ & Ethrel 200 & 103.92 & 109.72 & 119.88 & 121.42 & 78.37 & 86.68 & 12.82 & 10.44 & 37.44 & 42.15 \\
\hline $\mathrm{T}_{12}$ & ALAR 100 & 118.62 & 117.00 & 128.33 & 126.95 & 69.86 & 72.22 & 11.34 & 10.00 & 31.12 & 37.00 \\
\hline $\mathrm{T}_{13}$ & ALAR 200 & 119.00 & 117.94 & 129.10 & 128.78 & 64.96 & 72.09 & 11.01 & 10.01 & 31.56 & 36.15 \\
\hline $\mathrm{T}_{14}$ & MH 100 & 120.09 & 118.00 & 130.04 & 130.98 & 68.65 & 71.77 & 10.48 & 9.81 & 30.60 & 35.00 \\
\hline $\mathrm{T}_{15}$ & MH 200 & 120.35 & 119.39 & 131.54 & 131.30 & 64.01 & 70.32 & 10.10 & 9.75 & 30.59 & 34.78 \\
\hline & SEm \pm & 4.15 & 4.16 & 4.70 & 4.71 & 3.20 & 3.48 & 0.49 & 0.48 & 1.42 & 1.73 \\
\hline & CD at $5 \%$ & 12.02 & 12.05 & 13.61 & 13.66 & 9.28 & 10.09 & 1.43 & 1.39 & 4.12 & 5.01 \\
\hline
\end{tabular}


There was significant value found between $\mathrm{T}_{11}$ and $\mathrm{T}_{12}$ in both years of experimentation whereas difference between $\mathrm{T}_{5}$ and $\mathrm{T}_{6}$ was found significant in 2014-15. Such increase in plant height by capacity of $\mathrm{GA}_{3}$ to increase plant height has been attributed mainly due to its promontory effect of cell elongation. At the time of harvest the maximum number of leaves (9.96 and 9.80) in 2013-14 and 201415 , respectively per plant was in $T_{5}$ followed by $\mathrm{T}_{4}$ (9.65 in 2013-14 and 9.61 in 2014-15). In 2014-15 difference between $\mathrm{T}_{11}$ and $\mathrm{T}_{12}$ values were significant. Leaf width was obtained in $\mathrm{T}_{5}(3.66 \mathrm{~cm}$ in $2013-14$ and $3.78 \mathrm{~cm}$ in 2014-15) from corms treated with $200 \mathrm{ppm} \mathrm{GA}_{3}$ followed by $\mathrm{T}_{4}$ and $\mathrm{T}_{3}$, respectively. Treatments $T_{5}, T_{6}, T_{11}, T_{12}, T_{13}$ and $\mathrm{T}_{14}$, values were found significant over control in both years. The diameter of corm was significantly maximum with $200 \mathrm{ppm}$ $\mathrm{GA}_{3}\left(\mathrm{~T}_{5}\right)$ that was $7.90 \mathrm{~cm}$ followed by $\mathrm{T}_{4}$ $(7.79 \mathrm{~cm})$ and $\mathrm{T}_{3}(7.65 \mathrm{~cm})$ in $2013-14$ while during 2014-15 it was maximum $(8.45 \mathrm{~cm})$ with $\mathrm{T}_{5}$ followed by $\mathrm{T}_{4}(8.00 \mathrm{~cm})$ and $\mathrm{T}_{3}$ $(7.60 \mathrm{~cm}) . \quad T_{5}$ and $T_{6}$ values were found significant over control during both years of experimentation. The positive role of gibberellins in cell enlargement could be the reason for increased leaf width, number of leaves as well as diameter of corm. These observations are similar to the findings of Prasad et al., (2002) on effect of $\mathrm{GA}_{3}$ in gladiolus, Havale et al., (2008) on soaking of corm of gladiolus in $\mathrm{GA}_{3}$ solution, Mohanty et al., (1994), Misra et al., (1993) and also of Kumar et al., (2002) in tuberose using $\mathrm{GA}_{3}$ 200ppm, Rana et al., (2005) in gladiolus using $\mathrm{GA}_{3}$ 250ppm and Kumar et al., (2005) in gladiolus. The earliest spike initiation in case of dipping of corms was observed with the application of $\mathrm{GA}_{3}$ 200ppm followed by $\mathrm{GA}_{3}$ 100ppm. The earliest spike initiation (88.35 and 83.26 days in 2013-14 and 201415 , respectively) was observed with the treatment of $\mathrm{GA}_{3} 200 \mathrm{ppm}\left(\mathrm{T}_{5}\right)$. The number of days taken for first floret to open (103.36 and 96.26 days in 2013-14 and 2014-15, respectively) was noted in treatment $\mathrm{GA}_{3}$ $200 \mathrm{ppm}\left(\mathrm{T}_{5}\right)$ followed by $\mathrm{T}_{4}$ (106.22 and 103.87 days in 2013-14 and 2014-15, respectively) and $T_{3}$ (109.39 and 112.92 days in 2013-14 and 2014-15, respectively). There was no significant difference among treatments in both years of experimentation but in 2014-15 $T_{5}$ and $T_{6}$ were significantly different. The $\mathrm{GA}_{3}$ show significant effect on number of florets per spike and the number of florets per spike was noted maximum in $\mathrm{GA}_{3}$ 200ppm $\left(\mathrm{T}_{5}\right)$ (13.93and 14.11 in 2013-14 and 2014-15, respectively) followed by $\mathrm{GA}_{3}$ $100 \mathrm{ppm} \mathrm{T}_{4}$ (13.56 and 13.81 in 2013-14 and 2014-15, respectively). The longest spike length (91.11 and $99.00 \mathrm{~cm}$ in 2013-14 and 2014-15, respectively) was noted in $\mathrm{GA}_{3}$ $200 \mathrm{ppm} \mathrm{T}_{5}$ followed by $\mathrm{GA}_{3} 100 \mathrm{ppm} \mathrm{T}_{4}$ (90.78 and $98.26 \mathrm{~cm}$ in 2013-14 and 2014-15, respectively). Spike weight was highest in treatment $\mathrm{GA}_{3} 200 \mathrm{ppm} \mathrm{T}_{5}$ (40.68 and 50.82g days in 2013-14 and 2014-15, respectively). The spike lengths, spike weights and number of florets per spike were seen that ALAR $\left(\mathrm{T}_{12}\right.$ and $\left.\mathrm{T}_{13}\right)$ and $\mathrm{MH}\left(\mathrm{T}_{14}\right.$ and $\left.\mathrm{T}_{15}\right)$ treated corms were less than control $\left(\mathrm{T}_{1}\right)$ showed negative effect of these treatments on spike length. It might be due to enhanced cell division, cell enlargement and cell elongation and increase number of florets due to cell elongation. Similar findings were also reported by Devi et al., (2007), Faraji and Basaki (2013), Sharma et al., (2006) and Padmalatha et al., (2014) in their studies on effect of plant growth regulators on floral attributes of gladiolus.

\section{References}

Baskaran, V., Misra, R. L. and Abirami, K. (2007). Effect of plant growth regulators on corm production in gladiolus. Journal of Horticultural Sciences, 4(1): 78-80.

Devi, D. U., Sekhar, R. C. and Babu, J. D. (2007). Effect of growth regulators on 
flowering and corm production in gladiolus cv. Jacksonvilla Gold. Journal of Research ANGRAU, 35(1): 6-14.

Faraji, S. and Basaki, T. (2013). Evaluation of plant growth regulators on phonologic stages and morphologic traits of Gladiolus (White prosperity cultivar), International Journal of Agronomy and Plant Production, 4(7): 1549-1551.

Havale, V. B., Tawar, R. V., Hage, N. D., Kakad, G. J., Fathepurkar, S. C. and Sable, A. S. (2008). Effect of growth regulators and chemicals on growth and flowering of gladiolus. Asian Journal of Horticulture, 3(1): 93-94.

Kumar, R., Dubey, R., Mishra, R.L. and Mishra, S. (2002). Effect of $\mathrm{GA}_{3}$ on growth, flowering and corm production of gladiolus. Proceeding of the national symposium on Indian Floriculture in the new millennium, Lal bagh, Banglore, 25-27 Feb: 110-113.

Mishra, R.L., Tripathi, D.K. and Chturvedi, O.P. (1993). Implication of gibberellic acid spraying on the standing crop of gladiolus var. Sylvia. Prog. Hort. 25: 34, 147-150.
Padmalatha, T., Reddy, G. S., Chandrasekhar, R., Shankar, A. S. and Chaturvedi, A. (2014). Effect of pre planting treatment of corms with chemicals and plant growth regulators on vegetative growth, flowering and post harvest life in gladiolus. Indian Journal of Agricultural Research, 48 (4): 301-306.

Prasad, A., Kumar, R., Arya, S. and Saxena, K. (2002). Varietal response of gladioli corms to $\mathrm{GA}_{3}$ dippings. India, Journal of Ornamental Horticulture (New Series), 5(1): 69-70.

Schnelle, R., Cerveny, C., and Barrett, J. (2005). Factors affecting PGR liner dips. Greenhouse Product News, 15, 106-107.

Sharma, D. P., Chattar, Y. K. and Gupta, N. (2006). Effect of gibberellic acid on growth, flowering and corm yield in three cultivars of gladiolus. Journal of Ornamental Horticulture, 9(2):106-109.

Umrao, V.K, Singh, R.P. and Singh, A.R. (2005). Effect of gibberellic acid and growing media on vegetative and floral attributes of gladiolus. Indian J. Hort., 64: 73-76.

\section{How to cite this article:}

Rashmi and Bhagwan Deen. 2017. Effect of Pre-Soaking of Corms in to Plant Growth Regulators on Growth and Flowering of Gladiolus (Gladiolus grandiflorus L.) cv. American Beauty. Int.J.Curr.Microbiol.App.Sci. 6(12): 455-460. doi: https://doi.org/10.20546/ijcmas.2017.612.056 